\title{
Evaluation of the Accuracy of Implementation of Obstetric Referral Cases to the Emergency in the Jaminan Kesehatan Nasional (JKN) Era
}

\author{
Evaluasi Ketepatan Pelaksanaan Rujukan Kasus Gawat Darurat Obstetri \\ ke Instalasi Gawat Darurat dalam Era Jaminan Kesehatan Nasional
}

\author{
Omo A. Madjid, Arietta R.D. Pusponegoro, Immanuel S. Margatan \\ Department of Obstetrics and Gynecology \\ Faculty of Medicine Universitas Indonesia \\ Dr. Cipto Mangunkusumo General Hospital
}

Jakarta

\begin{abstract}
Objective : To investigate the circumstances of the obstetric referral case at the emergency department of the Dr.Cipto Mangunkusumo Hospital as well as the accuracy of the referral implementation.

Methods : We used cross-sectional study. Medical records of obstetric patients at Emergency department in RSCM in January 2013-July 2014 were obtained, then information about patients and their characteristic were collected. The accuracy of referral cases is based on emergency obstetric criteria by BPJS rules.
\end{abstract}

Results : Primary Health Care became the leading referrer. Inappropriate diagnostic referral cases amounted to 21.2\%when JKN first began to be implemented in 2014. Cases with improper diagnoses were more referred when JKN was implemented which amounted to $16.8 \%$ and nonemergency referral cases of $6.9 \%$ in 2014.

Conclusions : Referral implementation has not been efficient and effective, the number of obstetric referral cases to emergency department of RSCM that can actually be handled in the secondary advanced health services after the application of JKN is still high. Monitoring and evaluation is needed by the Local Health Office to improve the quality of the referral system that applied in the newly JKN era.

Keywords : accuracy of referrals, BPJS, JKN, obstetric emergencies, referral system.

\section{Abstrak}

Tujuan : Mengetahui gambaran kasus rujukan obstetri di IGD RSCM dan ketepatan pelaksanaan rujukan.

Metode : Deskriptif desain studi potong lintang. Data diambil dari rekam medis pasien obstetri di IGD RSCM pada bulan Januari 2013 hingga Desember 2014, kemudian informasi mengenai data dan karakteristik pasien dikumpulkan. Ketepatan pelaksanaan rujukan kasus gawat darurat obstetri berdasarkan Krietria gawat darurat bagian kebidanan menurut ketentuan BPJS Kesehatan.

Hasil : Perujuk terbanyak adalah Puskesmas (FKTP). Kasus rujukan dengan ketidaksesuaian diagnosis lebih banyak jumlahnya pada saat JKN mulai diterapkan pada tahun 2014 sebesar 21.2\%. Kasus dengan diagnosis yang tidak tepat rujuk lebih banyak pada saat JKN di laksanakan yaitu sebesar $16.8 \%$ dan kasus rujukan yang bukan gawat darurat sebesar 6.9\% pada tahun 2014.

Kesimpulan : Pelaksanaan rujukan belum efisien dan efektif, jumlah rujukan obstetri ke IGD RSCM yang sebenarnya dapat ditangani di fasilitas kesehatan tingkat lanjutan sekunder setelah penerapan JKN masih tinggi. Dibutuhkan monitoring dan evaluasi oleh Dinas Kesehatan setempat untuk meningkatkan kualitas sistem rujukan yang berlaku di era JKN yang baru diterapkan.

Kata kunci : BPJS, gawat darurat obstetri, JKN, ketepatan rujukan, sistem rujukan.

Correspondence author: Omo A. Madjid : omo.abdul.madjid@gmail.com

\section{INTRODUCTION}

Safe Motherhood is an effort to save women so that their pregnancies and deliveries are healthy and safe, and give birth to healthy babies. The aim of the Safe motherhood effort is to reduce maternal mortality. There are 4 strategic pillars that support this program, namely Family Planning, Antenatal Care, Clean and safe delivery, and Essential Obstetrics Services. ${ }^{1-3}$ Health financing is one of the main factors in improving general health services and specifically maternal and child health services. ${ }^{4-8}$

It is realized that limited funding is a big threat in achieving optimal health status. Health financing resources need to be explored more from existing sources in the community and directed to be more rational and efficient to improve service quality. This situation encourages the need for a strategic 
step in creating a holistic financing system that is often known as the Community Health Care Guarantee (CHCG). The important thing in health financing is how to use these costs effectively and efficiently from economic and social aspects and can be enjoyed by all people in need. The application of health financing with the insurance system will shift individual responsibility to group responsibility. ${ }^{9,10}$

Every pregnancy contains risks, therefore, every pregnant woman must have access to obstetric emergency services. To avoid the occurrence of ongoing complications, good and appropriate management is needed, which is supported by a good referral system. This referral system is structured in stages, starting with primary care with doctors, secondary services with specialist doctors, and tertiary services with sub-specialist doctors. ${ }^{11,12}$

With the enactment of the Jaminan Kesehatan Nasional program, it is necessary to evaluate the program whether the implementation of obstetric referrals is appropriate in accordance with the provisions of the BPJS, especially the obstetric referral cases to RSUPN Dr. Cipto Mangunkusumo as a national hospital, this can be used as an evaluation and consideration in health system policies.

\section{METHODS}

A cross sectional descriptive design was conducted for this study which illustrates the accuracy of obstetric referral cases to the Dr. Cipto Mangunkusumo Hospital RSCM IGD in 2013 and 2014 based on the diagnosis of obstetric emergencies according to the BPJS rule, before and during the National Health Insurance Program organized by BPJS. The inclusion criteria in this study were obstetric referral cases to RSCM emergency department in year 2013 and 2014. Whereas exclusion criteria include data on obstetric cases that are not referenced, referral case data of patients who died when they arrived at the RSCM Emergency Department before receiving treatment (Death on Arrival).
Subjects were taken by total sampling. Calculations were carried out univariate descriptive analysis to find out the distribution and normality. The result is in the form of frequency and percentage (proportion) which presented in the form of tables or graphs. Then all analyzes were carried out using SPSS 20.0.

\section{RESULTS}

The researcher succeeded in getting the research subjects as many as 5,223 people who were patients referring to obstetric cases at the RSCM Emergency Department throughout year 2013 and year 2014. The year 2013 was the era before JKN, and in 2014 was the JKN era. The number of subjects in year 2013 was 2,251 people, and in year 2014 there were 2,972 people.

To get a description of the pregnancy characteristics of subjects in the era before JKN and JKN era, researchers used several determinants, namely the number of parity, number of gravidas, number of ANC, gestational age, and number of fetuses. From the existing data, it was found that subjects with nullipara parity were the highest number, namely 1,179 people (52.4\%) in 2013 and 1,130 people (38.0\%) in 2014. In 2013, the number of subjects who had completed the minimum number of ANCs (four times) was 958 people (42.6\%), but there were still many who only conducted ANC three times, namely 919 people (40.8\%). In 2014, there were more subjects who had successfully completed the minimum number of ANCs, namely 2635 people (88.7\%), but those who had never done an ANC had also increased, namely 252 people (8.2\%). For gestational age subjects who were referred to the RSCM ED, there were differences in 2013 and 2014. In 2013, the majority of referrals to the RSCM ED were 29-36 weeks with 1.385 people (61.5\%). Meanwhile, in 2013, the majority of those referred to the RSCM ED were age > 37 weeks with 2.749 people (92.5\%). The highest number of fetuses is a single fetus, with 2.114 (93.9\%) in 2013 and 2867 people (96.5\%) in 2014. 
Tabel 1. Characteristic of Patients in Obstetrics and Gynecology at RSCM ED 2013-2014

\begin{tabular}{|c|c|c|c|c|}
\hline \multirow[t]{3}{*}{ Pregnancy characteristics } & \multicolumn{4}{|c|}{ Number of subject } \\
\hline & \multicolumn{2}{|c|}{ before JKN } & \multicolumn{2}{|c|}{ at JKN } \\
\hline & $n=2251$ & $\%$ & $n=2972$ & $\%$ \\
\hline \multicolumn{5}{|l|}{ Parity } \\
\hline Nullipara & 1,179 & 52.4 & 1,130 & 38.0 \\
\hline Primipara & 528 & 23.5 & 844 & 28.4 \\
\hline Multipara & 505 & 22.4 & 922 & 31.0 \\
\hline Grande multipara & 39 & 1.7 & 76 & 2.6 \\
\hline Gravida 1 & 1,144 & 50.8 & 1,081 & 36.4 \\
\hline Gravida 2 & 498 & 22.1 & 744 & 25.0 \\
\hline Gravida 3 & 399 & 17.7 & 797 & 26.8 \\
\hline Gravida $>3$ & 210 & 9.3 & 350 & 11.8 \\
\hline K1 & 263 & 11.7 & 12 & 0.4 \\
\hline $\mathrm{K} 2$ & 111 & 4.9 & 0 & 0 \\
\hline K3 & 919 & 40.8 & 73 & 2.5 \\
\hline K4 & 958 & 42.6 & 2,635 & 88.7 \\
\hline Never & 0 & 0 & 252 & 8.5 \\
\hline \multicolumn{5}{|l|}{ Age of pregnancy (weeks) } \\
\hline$<12$ & 284 & 12.6 & 38 & 1.3 \\
\hline $12-28$ & 106 & 4.7 & 0 & 0 \\
\hline $29-36$ & 1,385 & 61.5 & 185 & 6.2 \\
\hline$>37$ & 476 & 21.1 & 2,749 & 92.5 \\
\hline \multicolumn{5}{|l|}{ Fetus } \\
\hline Singleton & 2,114 & 93.9 & 2,867 & 96.5 \\
\hline Multiple & 137 & 6.1 & 105 & 3.5 \\
\hline
\end{tabular}

Primary Health Care remains the most frequent referral to RSCM. Based on its location, in 2013 and 2014 the most referrer were from Central Jakarta with 1105 people (49.1\%) and 1155 people (28.9\%) respectively

Table 2. Characteristics of Obstetric Patient Referrers at RSCM ED 2013-2014

\begin{tabular}{lcccc}
\hline Referrer Characteristic & \multicolumn{4}{c}{ Number of subject } \\
\cline { 2 - 5 } & \multicolumn{2}{c}{ before JKN } & \multicolumn{2}{c}{ at JKN } \\
& $\mathbf{n}=\mathbf{2 2 5 1}$ & $\%$ & $\mathbf{n = 2 9 7 2}$ & \% \\
\cline { 2 - 5 } Referrer location origin & & & 1.155 & 38.9 \\
Central Jakarta & 1,105 & 49.1 & 743 & 25.0 \\
East Jakarta & 561 & 24.9 & 185 & 6.2 \\
West Jakarta & 114 & 5.1 & 562 & 18.9 \\
South Jakarta & 322 & 14.2 & 178 & 6.0 \\
North Jakarta & 102 & 4.5 & 9 & 4.7 \\
Other Location & 47 & 2.0 & & \\
Referrer Type & & & 139 & 4.7 \\
Hospital & 175 & 7.8 & 502 & 16.9 \\
Type A & 264 & 11.7 & 28 & 0.9 \\
Type B & 28 & 1.2 & 30 & 1.0 \\
Type C & 10 & 0.4 & 2 & 0.1 \\
Type D & 8 & 0.4 & 34 & 1.1 \\
Mother and Child Hospital & 48 & 46.3 & 1,548 & 52.1 \\
Maternity Home & 1,043 & 46.3 & 651 & 21.9 \\
Primary Health Care & 604 & 26.8 & 34 & 1.1 \\
Midwife & 43 & 1.9 & 4 & 0.1 \\
Obstetric and Gynecology doctor & 28 & 1.2 & & \\
GP & & & & \\
\hline
\end{tabular}


The characteristics of the obstetric referral case to the RSCM ED are also sought by the researcher. For this reason, what is examined is the diagnosis of the referrer whether it is correct or not then the reason why the patient is referred, and whether the referral is accompanied by a backreferral letter or not. The results show that most diagnoses are correct, although in 2014 the number of incorrect diagnoses increased. Most of the reasons patients are referred are due to facility problems. While, for a reverse reference letter, no referrer includes a reverse reference letter.

Table 3. Characteristics of Obstetric Referral Cases to RSCM ED 2013-2014

\begin{tabular}{lcccc}
\hline \multirow{2}{*}{$\begin{array}{l}\text { Case } \\
\text { Characteristic }\end{array}$} & \multicolumn{4}{c}{ Number of subject } \\
\cline { 2 - 5 } & \multicolumn{2}{c}{ before JKN } & \multicolumn{2}{c}{ at JKN } \\
\cline { 2 - 5 } Diagnose & 1,994 & 88.6 & 2,317 & \% \\
\cline { 2 - 5 } $\begin{array}{l}\text { Appropriate } \\
\text { Inappropriate }\end{array}$ & 230 & 10.8 & 630 & 21.2 \\
Reason to Referr & 2,123 & 94.3 & 2,815 & 94.7 \\
Facility & 56 & 2.5 & 52 & 1.7 \\
Human Resource & 72 & 3.2 & 105 & 3.5 \\
Full booked & & & & \\
Reverse Referral request & 0 & 0 & 0 & 0 \\
Accompanied by referral letter & 2,251 & 100 & 2,972 & 100 \\
Without reverse referral letter & & & & \\
\hline
\end{tabular}

Table 4. The Accuracy of the Implementation of Referral of Obstetric Cases to the Emergency Department of RSCM

\begin{tabular}{lcc}
\hline Reference & \multicolumn{2}{c}{ Number of Subject } \\
\cline { 2 - 3 } Accuracy & $\mathbf{n}$ & $\%$ \\
Case with correct diagnosis to refer & & \\
Year 2013 (before JKN) & 2,019 & 90.7 \\
Year 2014 (JKN Era) & 2,452 & 83.2 \\
Case with the incorrect diagnosis to refer & & \\
Year 2013 (before JKN) & 206 & 9.3 \\
Year 2014 (JKN Era) & 495 & 16.8 \\
\hline
\end{tabular}

In this study, the results of the accuracy of referral of referral obstetric patients in RSCM IGD in 20132014 generally decreased, as many as 2019 cases (90.7\%) in year 2013 and 2452 cases (83.2\%) in 2014

\section{DISCUSSION}

The research subjects were 5223 people who were divided into patients referring obstetric cases at the RSCM IGD in year 2013 and year 2014.

Patient's pregnancy characteristics change with the implementation of the JKN system. The characteristics of the highest number of patient parity in 2013-2014 were nullipara patients, there was a decrease in the percentage of nullipara patients, from 1.144 people (50.8\%) to 1081 people (36.4\%). This trend continues for obstetric referral patients at the RSCM Emergency Department since 2008 where the value of nullipara patients in 2008 to RSCM was $43.9 \%$. The gestational age of the study subjects experienced a shift from the most gestational age, namely 29-36 weeks for 2013 (61.5\%) to more than 37 weeks for 2014 (92.5\%).

Furthermore, there was a significant increase in the variable antenatal care visit of patients referring to obstetric cases at the RSCM ED after the implementation of JKN. Previously, the number of patients who had completed the 
minimum number of ANCs recommended by WHO four times was only 958 people (42.6\%), whereas after the application of JKN, the number had increased to 2,635 people ( $88.7 \%$ ). This shows that there are improvements in ANC services after the implementation of the JKN system. This can be caused by reduced barriers to finding health services related to cost issues. However, it was also seen that patients who had never done ANC had also increased to 252 people (8.2\%) from none before. This phenomenon shows an effort to look for maternal health services in patients who may have been hindered due to cost problems, because patients who had never done ANC which might be due to limited funds and also increased public knowledge and awareness in understanding maternal emergencies to seek help in competent health facilities.

Based on location, referrals from the Central Jakarta area were still the locations with the most referrers, from as many as 1,105 people (49.1\%) to 1,155 people (38.9\%), but there was a decrease in percentage along with the increase in the percentage of other referral locations. This illustrates the improvement in the patient's referral system, where in the JKN program, patient referrals are implemented in the first level health services and advanced health facilities regional areas where patients live and the regional referral system runs.

The most health care facilities referring obstetrics and gynecology patients are still primary health centers, from the percentage of $46.3 \%$ in year 2013 to $52.1 \%$ in year 2014 . These figures are accompanied by a decrease in referrals from type A and Mother and Child Hospital RSIA hospitals and an increase in hospital referrals type B significantly indicates an increase in the health referral system when JKN is applied. Primary health care as first level health services should not directly refer to tertiary first level health services but to secondary advanced health services according to the tiered referral pathway implemented by BPJS, but many other factors influence the event, one of which is the request of patients to be referred to certain advanced health services, related to distance, level of trust, availability of facilities, health resources, and certain subspecialties, but this will burden health financing at the tertiary advanced health services level if the case can actually be handled in the secondary advanced health services.

The percentage of diagnoses that are not inappropriate for obstetric case reference patients has increased by almost three fold, from 230 cases $(10.8 \%)$ in year 2013 to 630 cases $(21.2 \%)$ in year 2014. While the reason for the highest number of referral patients is still caused for reasons of limited facilities.

During 2013-2014 no referred patients to obstetric cases at the RSCM emergency room accompanied by a back-referral letter. In fact, the obstetric cases that might be handled in primary care after the emergency has been resolved. This shows that there are differences in the ability to diagnose a maternal emergency case at the first level health service and advanced health services levels. Health human resources are certainly needed in providing quality health services, in addition services that are always available with the presence of health workers play an important role in facing maternal emergency cases, such as there is a specialist physician and the availability of emergency operating rooms whenever needed. This phenomenon shows the ineffectiveness and inefficiency of handling referral cases, by burdening health costs and accumulating cases in advanced health serviceswhich should be handled in secondary advanced health services. The accuracy of obstetric referral case in RSCM ED generally decreased significantly. Referral cases with the appropriate diagnosis of referral as much as $90.7 \%$ (2,019 cases) in 2013 to $83.2 \%$ $(2,452$ cases $)$ in 2014 . These cases should have been resolved at lower levels of health care facilities. A similar phenomenon can also be seen in health centers with other services. For inappropriate referral cases in 2013 there were 206 cases (9.3\%) to 495 cases (16.8\%) in 2014.

The effectiveness of the maternal referral system can be seen from the indicators of conformance and time. Conformance is the suitability of the reference made, namely bypassing (the reference made is not in accordance with the predetermined stage of reference, namely passing a lower health facility) and non compliance with referral advice (referral that should not be necessary)..$^{13}$ Where as long as the reference is important to note, whether it is in accordance with the reference path or not. Besides that, it can also be caused by self referrals 
(referrals made by pregnant women themselves, where the pregnant women come directly to health facilities at a higher level, without going to low-level health facilities first). The second indicator used is time, this is related to response time for communication (the time needed to communicate with facilities where pregnant women will be referred) and timely treatment of complication (speed in handling complicated cases in referral health facilities). ${ }^{14-15}$ Distance factors can also cause obstacles in the referral process, this is because there is an emergency so that the patient or referrer will choose the closest first level health service at that time, this also actually can not be separated from social and cultural factors, the level of trust in certain health facilities.

High-risk or complicating pregnancies are the most cases obtained, which amounted to 1772 cases $(78.7 \%)$ in 2013 and 2428 cases $(81.8 \%)$ in 2014. Further more, the second and third most frequent cases of emergency also included abortion (5.3\%) and dystocia (4.8\%) for 2013 as well as abortion (5.1\%) and antepartum bleeding (2.4\%) for 2014. Whereas it can be seen a decrease in cases others. Primary health care is the referral facilities with the highest number of false emergencies in 2013 - 2014. This incident caused abuse of maternal health funding in the JKN system, whereas cases that should not be referred to because it is not an emergency case. This can actually be minimized if the role of first level health serviceas a gatekeeper in the national referral system is good.

The number of obstetric referral patients at the RSCM increased after JKN implemented, from as many as 2251 patients in 2013 to 2972 patients in 2014 , an increase of $16.5 \%$. This is the opposite of JKN's aim to make the reference level better so that not all patients need to be referred to RSCM as a national referral center hospital. The percentage of type A hospitals as referral health care facilities decreased from $7.4 \%$ in 2013 to $4.7 \%$ in 2014, while referrals from type D hospitals and health centers increased, each increasing from $0.4 \%$ to $1.0 \%$ for type D hospitals and $46.3 \%$ for $52.1 \%$ for primary health care. This shows more patients who skip the reference level and go directly to the RSCM as type A hospital. After the implementation of JKN there was more diagnosis cases that inappropriate, from $10.8 \%$ in 2013 to
$21.2 \%$ in 2014, more than double the increase in the diagnosis of inappropriate referrals. In addition, there was an increase in cases with an incorrect diagnosis of referral cases from $9.3 \%$ in 2013 to $16.8 \%$ in 2014.

The data above shows that when the JKN was implemented there was a decrease in the quality of referrals.

\section{CONCLUSION}

The number of referral of maternal cases to RSCM IGD in 2013 was 2251 to and in 2014 there were 2972 cases. Of these, none of the referrers included a back-referral letter. This increase in the number of referrals was due to the enactment of the newly implemented JKN program, this was due to the lack of socialization and lack of understanding of the rules in the newly implemented JKN. The Antenatal Care K4 visit on the demographic picture of patients at the time JKN was applied experienced an increase of 958 (42.6\%) in 2013 and in 2014 there were 2635 $(88.7 \%)$. This increased number of visits is due to the reduced barriers to obtaining health services, namely the financing factor where the national insurance system is applied.

The number of appropriate referral cases based on BPJS emergency criteria in 2013 was $90.7 \%$ and 2014 was $83.2 \%$. The suitability of the reference diagnosis in 2013 was $88.6 \%$ and in 2014 it was $78.1 \%$. The data shows the need for improvement, especially in health human resources and the role of PKM as a gate keeper and increasing the role of secondary advanced health services in the referral system in the JKN program.

Primary health care is the most health facilities that make referrals to RSCM emergency department. The most reason being referred to is due to limited facilities. This indicates a lack of effectiveness and efficiency in referencing maternal cases.

Therefore, continuous socialization should done by BPJS in implementing the JKN rules that have just been implemented by the government, the phenomena that occur are due to the process of adaptation to the new system. Improving the quality of human resources, improving and 
improving facilities in first level health service is needed in empowering PKM as a gatekeeper in the JKN system. Better cooperation is needed between health facilities in the success of the JKN program in order to reduce the cost burden and stack of referral cases in advanced health services and abuse health funding. Also routine evaluation is need to perform by policy holders to assess the suitability and accuracy of the referrals to improve the referral system, especially maternal referrals because maternal health reflects the level of welfare of the country.

\section{REFERENCES}

1. Jowett M. Safe motherhood interventions in lowincome countries: an economic justification and evidence of cost effectiveness. Health Policy. Elsevier; 2000;53(3):201-28.

2. Mahler $\mathrm{H}$. The safe motherhood initiative: a call to action. The Lancet. 1987;1(8534):668-70.

3. Benagiano G, Thomas B. Safe motherhood: The FIGO initiative. Int J Gynecol Obstet. 2003;82(3):263-74

4. Mati K, Adegoke KK, Michael-Asalu A, Salihu HM. Health insurance coverage and access to skilled birth attendance in Togo. Int J Gynecol Obstet. 2018 ;141(2):181-8.

5. Philibert A, Ravit M, Ridde V, Dossa I, Bonnet $E$, Bedecarrats F, et al. Maternal and neonatal health impact of obstetrical risk insurance scheme in Mauritania: a quasi experimental before-and-after study. Health Pol Plan. 2017;32(3):405-17.
6. Ekman B, Liem NT, Duc HA, Axelson H. Health insurance reform in Vietnam: a review of recent developments and future challenges. Health Policy and Planning. Oxford University Press; 2008 1;23(4):252-63.

7. RI KIDJKKK, 2013. Buku Pegangan Sosialisasi Jaminan Kesehatan Nasional dalam Sistem Jaminan Sosial Nasional [Internet]. Kemenkes RI; 2013:76

8. RI P Peraturan Presiden no 12, tahun 2013,tentang Jaminan Kesehatan Peraturan Presiden 2013.

9. Persada WAJPR, Sistem Kesehatan Nasional. Staff blog ui.ac.id. 2007

10. RI P. Undang-undang no 40, tahun 2004 , tentang Sistem Jaminan Sosial Nasional. 2004:1-36.

11. Indonesia Menteri Koordinator Bidang Kesejahteraan Rakyat P. Peraturan Pemerintah Republik Indonesia dan Peraturan Presiden Republik Indonesia : sistem jaminan sosial nasional (SJSN) dan Badan Penyelenggaraan Jaminan Sosial (BPJS).2018

12. RI K. PMK No. 001 tentang Sistem Rujukan Pelayanan Kesehatan Perorangan. 2012:1-10.

13. Murray SF, Pearson SC. Maternity referral systems in developing countries: Current knowledge and future research needs. Soc Sci Med. 2006 ;62(9):2205-15.

14. RI K. Sistem Kesehatan Nasional Per Pres 72 tahun 2012. 2013:1-45.

15. Irasanty $G$, Hasanbasri $M$, Hakimi M. Efforts to minimize delays in maternal referral in Majene District - Indonesia (Pencegahan Keterlambatan Rujukan Maternal di Majene Indonesia).2008 